\title{
REFERENCES
}

BLOOMFIELD J.(2012), TOGETHER Final Report. Available online at: http://www.forumdascidades. $\mathrm{pt} /$ sites/default/files/Projetos/together_final_report_rev.pdf

Dahlvik J., Engkvist R., Franz Y., Hoekstra M., Kohlbacher J. (2016), Towards a better understanding of "interethnic co-existence. ICEC Newsletter \#4. Available at: www. icecproject.com

Edwards-Schachter M. E., Matti C. E., Alcántara E. (2012), Fostering Quality of Life through Social Innovation: A Living Lab Methodology Study Case. Review of Policy Research 29(6), pp. 672-692.

Franz Y. (2014), Chances and Challenges for Social Urban Living Labs in Urban Research. ENoLL - European Network of Living Labs (2014): Conference Proceedings of Open Living Lab Days 2014, pp. 105-114. ISBN: 9789082102727.

Franz Y. (2015), Designing social living labs in urban research. Info - The journal of policy, regulation and strategy for telecommunications, information and media, 17(4), pp. 53 66.

Franz Y., Tausz K., Thiel S.-K. (2015), Contextuality and Co-Creation Matter: A Qualitative Case Study Comparison of Living Lab Concepts in Urban Research. Technology Innovation Management Review, 5(12), pp. 48-55.

Hoekstra M. (2014), Super-diversity and urban policies in Amsterdam. ICEC Baseline Study. Available at: www.icecproject.com

Hoekstra M. (2015), Diverse cities and good citizenship: how local governments in the Netherlands recast national integration discourse. Ethnic and Racial Studies, 38(10), pp. 1798-1814.

Hoekstra M. (2017), Verbinding creëren in de buurt door beleidsinterventies [Creating connections in the neighbourhood through policy interventions]. In: De wereld in één stad: migratiediversiteit en stedelijk beleid in Europa [The world in one city: migration-related diversity and urban policy in Europe]. The Hague: WRR.

Hoekstra M. \& DahlviK J. (2017), Neighborhood Participation in Super-Diverse Contexts: Comparing Amsterdam and Vienna. In: Urban Research \& Practice. doi: 10.1080/ 17535069.2017.1390780.

Kohlbacher J., Schnell Ph., Reeger U., Franz Y. (2014), Super-diversity and urban policies in Vienna. ICEC Baseline Study. Available at: www.icecproject.com

Matejskova T., Leitner H. (2011), Urban Encounters with Difference: The Contact Hypothesis and Immigrant Integration Projects in Eastern Berlin. Social \& Cultural Geography 12 (7), pp. 717-41. doi:10.1080/14649365.2011.610234.

Pascu C. \& VAn Lieshout M. (2009), User-led, citizen innovation at the interfacce of services. Info - The journal of policy, regulation and strategy for telecommunications, information and media, Vol. 11(6), pp. 82-96.

Valentine G. (2008), Living with Difference: Reflections on Geographies of Encounter. Progress in Human Geography 32 (3), pp. 323-37. doi:10.1177/0309133308089372.

Vertovec S. (2007), Super-Diversity and Its Implications. Ethnic and Racial Studies 30 (6), pp. 1024-54. doi:10.1080/17535060902727066. 


\section{OnLine References}

Urban Renewal Office in Vienna for the districts 7/8/16:

http://www.gbstern.at/ueber-die-gb/standorte/gb7816/16-bezirk/, Last access: 29-08-2017.

Urban Renewal Office in Vienna for the districts 6/4/15:

http://www.gbstern.at/ueber-die-gb/standorte/gb61415/, Last access: 29-08-2017.

ICEC research project:

www.icecproject.com/project/theory, Last access: 29-08-2017.

Matznergarden community garden in Vienna:

www.matznergarten.at, Last access: 29-09-2017.

Neighbourhood initiative in Vienna:

http://miteinander.mariahilf.wien.gv.at/, Last access: 29-09-2017.

Pek-O-Bello, neighbourhood initiative in Amsterdam:

www.pek-o-bello.nl/, Last access: 29-09-2017

VoorUit, neighbourhood initiative in Amsterdam:

www.vooruitproject.nl

De Handreiking, neighbourhood initiative in Amsterdam: www.buurtwerkkamer.nl/buurtwerkkamers/de-handreiking

De Vrouwenbazaar, neighbourhood initiative in Amsterdam:

www.buurthuisvdpek.nl/buurtvereniging-van-der-pek/de-vrouwenbazaar/ 